\title{
TRANSKEIAN MIGRANT WORKERS AND YOUTH LABOUR ON THE NATAL SUGAR ESTATES, 1918-1940
}

\author{
William Beinart
}

\section{1. "A most ghastly and helpless state" [1]}

The story begins with a corpse. Early in the New Year of 1922, Mr Larsen, the Station Master at Izingolweni in southern Natal, found a youth travelling "in a most helpless and pitiful condition ... quite unable to walk when taken out of the train". [2] Isingolweni was a small station, opened less than a decade before, on a single track, narrow gauge line snaking through the hills inland from Port Shepstone. The line was built largely to open a transport route for agricultural produce from the still isolated districts of southern Natal. It was, however, the closest Natal station to Pondoland and rapidly became the railhead for migrant workers draining from the Transkeian Territories. [3]

The boy stated that he came from Messrs Reynolds' Sugar Estate and was bound for Lusikisiki (a distance of 100 miles from Izingolweni). This boy was conveyed by wheelbarrow to a hut situate on hotel property which is generally used by natives recruited in Pondoland. [The] hotel proprietor was kind enough to attend and feed the boy but despite this attention the unfortunate lad died ... and was buried same day. [4]

Faka, the "unfortunate lad", was severely emaciated. All he had was his travelling pass, a cloth and 7/6 in silver; he was about fourteen years old.

Larsen was sufficiently perturbed to take a photograph and report the incident to the nearest Magistrate at Harding. Faka was by no means the first; "natives are continually arriving at Izingolweni station from various Sugar Estates in a state of collapse and frequently die within a few hours after arrival". [5] The Magistrate at Harding saw no urgent cause for action and subsequently "lost" most of the correspondence about this and other incidents.

By September 1922, Larsen could no longer cope with the dead and dying at the station. He had handed the responsibility over to the police in the shape of Lance Sergeant Swartz, commander of the local Moguntia post. In October and November Swartz found himself little more than an undertaker. In one two-day spell he dealt with four corpses, including "a male native lying dead in an old hut on the hotel premises" and another "in the act of dying in the waiting room". [6] Tired and disturbed, Swartz sent a detailed report to his superiors. Local people attempted to avoid the corpses. The Deputy Commissioner of Police for Natal, under the impression that some virulent infectious disease had broken out, slapped a quarantine notice on the police post.

The District Surgeon was eventually called in to hold post-mortems (copies of which were also subsequently lost by the Magistrate). [7] It was not least this involvement of the Department of Health that set bureaucratic wheels spinning more rapidly. A joint Departmental Committee was appointed to sit in March 1923. Dr J Park Ross, Assistant Health Officer for the Union (Natal), was the driving force behind it and he was more prone than the magistrate to a little detective work. Deaths were difficult to quantify but the Committee examined the records of 25 cases of people who died at Izingolweni in 1922; there were many other deaths in early 1923 , on the fields themselves, or further along the routes into Pondoland. 
It is not clear what disease killed Faka and why he did not use his last $7 \mathrm{~s} 6 \mathrm{~d}$ to buy food. The Committee found no sudden spread of infectious disease amongst these migrant workers returning from the sugar fields. It found scurvy, tuberculosis, pneumonia, dysentery, some "heart disease", and silicosis or phthisis. Park Rose emphasized that at least some of these diseases were preventable by basic regulation and improvement of the housing, diet and medical facilities available to workers on the sugar fields. Many workers fell ill, some shortly after arrival on the estates, either because of the inadequate diet and conditions or because these exacerbated existing problems.

To keep sick workers on the fields, even if they were not being paid (and they were not), cost money. The workers' contracts, where they had them, specified that they would receive free medical attention. But the estates perceived themselves to be under acute financial pressure and the tendency was to work sick workers for as long as possible and then dispatch them home as quickly as possible when they became incapable. Sick workers were usually given a cursory medical examination before being despatched to Izingolweni. Reynolds Bros at Sizela and Crookes at Renishaw, from where most of the 1922/23 cases came, could then argue that, once workers were certified fit to travel, the estates' responsibility ended. The doctor in question argued, when examined by the Committee, that "due regard must be given to the economic side of the question". Not all officials in Natal were as incurious as the Magistrate of Harding as to what was happening; but they had relatively little power to intervene. Moreover, as Frank Brownlee, the old Transkeian magistrate, put it a few years later: "the people in Natal regard natives generally from a different point of view to what we do. They are more harsh towards the Native." [8]

The Committee made a number of recommendations for the improvement of diet, conditions and medical facilities on the estates and for routine medical examinations before recruitment and before workers travelled home. Park Ross attempted to use the episode to embarrass the estates into immediate reforms. Both he and many. Transkeian officials advocated the extension of the Native Labour Regulation Act (15 of 1911), which controlled the system of migrant labour in the mining industry, to the sugar estates as well. In addition to health regulations, it was the control of youth and child labour which they felt to be the most urgent need. Poor Faka was by no means the only youth who ran into difficulties on the sugar estates at this time.

But, for the next two decades, reforms were systematically blocked. Conditions on at least some of the sugar estates were a recurrent cause for concern; officials saw the Rand mines as more favourable places to work despite the rigours of underground labour, huge compounds and the social problems which attended these. When people less sympathetic to the sugar industry penetrated into the world of the cane fields, they found what they considered a variety of suppressed scandals. The death of fourteen-year old Faka at Izingolweni in 1922 perhaps reflected some of the worst excesses, but it can be seen as symptomatic of a system of employment which persisted for many years afterwards.

\section{2. "A seriousness quite beyond their grasp" [9]}

Sugar cane, wherever it has been grown on a large scale for export, has been a crop hungry for labour. Unless cane is milled shortly after harvest, it loses its sucrose content rapidly; investment in processing works near the cane fields was essential. Once such investments had been made, producers had to find enough cane for continuous operation of the mill during the harvest season (in South Africa from May to December). Sugar cane production, which necessarily involved close co-ordination between agricultural and industrial processes, put a premium on a steady and controlled labour supply during part of the year, but also the capacity to diminish the work-force rapidly in the off-season. 
Over the centuries sugar cane has been at the core of coercive labour systems demanding a great deal of "human blood, sweat and gall". [10] After the abolition of slavery, plantations expanded within the British empire on the basis of indentured wage workers in such diverse sub-tropical colonies as Fiji, Mauritius, Trinidad, Queensland and Natal. [11] The Empire's impoverished, recruited especially in the Indian subcontinent, became part of a population movement less brutal or final than the slave trade but nevertheless one with important and varied implications.

The impetus for the importation of indentured labour in Natal was shaped initially by the success with which local African communities could resist demands for labour, even after conquest. Migrants recruited from afar on long contracts, from both India and Mozambique, came to be seen as a more reliable and controllable labour force for the estates than farm tenants, daily (togt) labourers or short-term migrants from Natal's many small locations. The age of Indian indentures was, however, relatively short-lived. By the time of Union, political conditions in India, in South Africa and in Britain made the large-scale organized decantation of Asian workers unpalatable to many different interest groups.

Intercontinental labour migration had been pursued because some nineteenth-century plantations had been enclaves in colonial possessions where the indigenous population had either been displaced or was as yet relatively independent. The processes of conquest and incorporation were more complete in southern Africa by 1911, when Indian indentured immigration was halted. Natal and Zululand were the obvious areas for estate owners to turn to and some local workers were secured. But better paid employment on the Rand and in Durban attracted local workers away from the fields; employers were also reluctant to "fall back on a man who could not be depended on to work for more than a month or two at a time". [12] A secure source of long-contract migrants was still favoured. The great majority of workers from southern Mozambique had, however, switched by the 1890 s to the gold mines of the Transvaal, where they formed by far the largest element in the underground work force. [13] Estate owners foresaw a major labour crisis.

The 1913 Indian workers' strike, perhaps the largest and most successful that there has ever been on the Natal sugar fields, fulfilled the estate owners' worst predictions. [14] Empowered by their employers' difficulties, angry at the harsh demands made on them, field workers brought production to a halt. The haemorrhage of Indian workers after the strike was not as rapid as estate owners feared, partly because wage rates were pushed up. But many of those doing field work melted away.

Exposed to the cold winds of competition, the instinct of colonial planters was to turn to the state. [15] They wanted to maintain and extend restrictions on mine recruiting in Natal and Zululand in order to bottle up the domestic labour supply. And, as in times of difficulty in the nineteenth century, they looked north - now to the area beyond 22 degrees latitude, which included most of Rhodesia and Mozambique besides the mine-dominated south. [16] The Natal Coast Labour Recruiting Corporation was established in 1916, primarily to exploit this potential supply. Well organized in local groups, as well as representative bodies such as the Natal Sugar Association and the two Planters' Unions of Natal and Zululand, sugar growers and millers were determined not to be caught flat-footed by shifts in government policy again.

But recruitment for the mines in these "tropical" areas had been halted in 1913 because of high death rates from pneumonia. Despite applying maximum pressure, agricultural enterprises such as the sugar estates could not get more than occasional exemptions from the restrictions. [17] The government was also reluctant to sanction the bottling up of labour in Natal. Pritchard, the Director of Native Labour, saw his priority as the mining industry. Cape officials with liberal inclinations, particularly Secretaries of Native Affairs Dower and Barrett, were still an important influence and they deployed the discourse of a free market in labour; they also displayed some concern about the conditions under which workers lived and worked. They felt that the large potential labour supply within Natal could be mobilized 
if adequate wage rates were paid by estate owners.

On the one hand the Natal employers say that the Natives are too lazy to work. On the other hand they complain that the Natives are freely recruited to work at mine rates which they cannot afford to pay ... The whole truth of the matter is that the large employer of labour in Natal for years past has mainly got his labour under conditions approaching those of servility. The source of this supply is, in fact, not now available. As a result it is up to him to put his "house in order" and in future cater to the local supply. [18]

These official protestations should not be taken to imply that they had the power to impose their ideals. By 1918, the government had sanctioned restrictions on recruiting by outside enterprises in some Natal and Zululand districts.

Officials were even less successful in regulating conditions of employment which, they felt, would both assure a labour supply to the fields and safeguard minimum standards in what they saw as becoming a semi-industrial sphere. The Native Labour Regulation Act of 1911 was an obvious and immediately available means to impose control, but only applied to designated industrial labour districts. Labour relations on the great majority of farms, most of which still operated through systems of tenancy, precluded the extension of such regulations to agriculture; nor would farmers have allowed such a measure to be passed. Sugar planters were investigating possible supplies of settled African family labour to replace Indians. But they primarily aimed to extend the use of African migrant workers leading a trend which was to become more general in large-scale capitalist farming enterprises. The planters' associations nevertheless insisted on their "agricultural" status. Estate owners thought that regulation of recruitment and conditions under the 1911 Act would lead to prohibitive expenses.

It was Transkeian workers who partly resolved the problems of the estates from the late 1910s. One of the key early recruiters involved was Douglas Mitchell, later Administrator of Natal and long serving conservative United Party MP, who became involved in the Natal Coast Recruiting Corporation as a young man. The family farm in southern Natal was beyond the sugar belt; trading and recruiting were a lucrative alternative. Known to workers as "Ubejana", the rhino, because of his quick temper and impenetrable hide, his local connections in the densely populated region of southern Natal and Pondoland provided a network along which to mobilize supplies. By 1923, when the deaths at Izingolweni were investigated, there were probably 2-3,000 workers from Pondoland in Natal; by 1930, the number had increased to perhaps 7,000 out of about 30,000 field-workers. [19] An increase in the local supply within Natal and Zululand, coupled with some migrants from Mozambique, provided most of the rest of the field-labour force.

Specific economic difficulties helped to push more people from Pondoland on to the labour market at this time. Influenza cut a swathe through the rural population in 1918, leaving some homesteads short of both agricultural labour and wages: the inflationary spiral after the First World War hit hard at any homestead dependent on some wage income. Mine recruiting slowed around the early 1920 s when the industry was in crisis. But there were also features of labour on the sugar fields which helped assure the estates of a longer-term supply. Some able-bodied workers went to the fields rather than the mines, despite lower wages, because of the availability of above-ground work, the relatively short (six-as opposed to nine-month) contracts offered, and the advance system. [20] Estate owners railed against advances because they facilitated desertion, but there is no doubt that their availability from sugar recruiters, following their abolition by the Native Recruiting Corporation, was a major factor in attracting workers from Pondoland.

But the sugar fields also came to rely for some of their supply on two pools of workers from Pondoland unavailable to the mines precisely because of the lack of state control. One group 
were workers rejected by the mines on the grounds of health. This is why a few of those who died at Izingolweni in 1922 and 1923 had miners' phthisis contracted on the Rand. Another were youths and children. [21] Many estates were desperate for labour in the late 1910s and 1920s: they welcomed youths, the sick and the lame. Some estates were prepared to dispense with them as soon as they became unproductive.

\section{3. "The opposition of the Sugar Planters has always defeated us" [22]}

State intervention in some spheres and the lack of it in others proved of some significance in resolving the labour crisis on the estates at this time. But officials in some departments were uneasy about the system that had come into being and had been so clearly exposed by the 1923 Committee. They persisted in their struggle for control during the inter-war years.

The lack of uniformity amongst sugar producers was one major problem which they encountered. The large miller/planter concerns such as Tongaat, Natal Estates, Crookes and Reynolds, which both grew and milled cane, were sometimes prepared to consider reform. But there were many smaller-scale white planters with no milling facilities; because of their numbers they were not without influence. This applied especially to the Zululand planters whose estates had been carved out in the coastal areas in the first decade of the century. They were most marginal producers and most vehement in blocking any reform which implied expense.

The political power of the planters and millers, who were perhaps becoming the most organized agricultural interest in the country, was considerable. With the exception of the Departments of Native Affairs and Health, the state's major concern in relation to the sugar industry was not labour but production, prices and marketing. During and after the First World War, increased emphasis was placed in national policy on self-sufficiency in basic staples; up to that time, South Africa, while exporting a wide range of pastoral products, had been a net importer of food, including sugar. The sugar growers were able to negotiate successive measures to protect themselves against the import of Mauritius and Mozambique sugar. [23] In 1926, the Fahey conference agreement helped to resolve conflicts within the sugar industry; at the same time the import duty on sugar was almost doubled from $£ 4.10 \mathrm{~s}$ to $£ 8$ a ton. In 1932, when prices fell in the depression, it was doubled again, although the government imposed a maximum local price. The 1936 Sugar Act, passed after complex and protracted negotiations, extended very considerable powers to the sugar producers to regulate their own industry, including production quotas and prices, subject to the maximum local price stipulated by the government.

These various supports played a considerable part in allowing the rapid expansion of production in the inter-war years, despite international price fluctuations, uncertain weather, and locusts in 1933. Production nearly quadrupled from about 126,000 tons in 1918 to a little under 600,000 tons in 1940. Between 1918 and 1932, both production and the area cultivated doubled, thus enormously increasing the demand for labour. Sugar was one of the first agricultural commodities, with wine, to receive such systematic support and regulation. By 1939, the cost of protecting sugar production was estimated to be higher in absolute terms (at £2.3 million a year) than any other commodity, although sugar ranked only seventh, by value, amongst those produced by white farmers (after meat, wool, maize, fruit, milk, and wheat). [24]

It may appear an anomaly that sugar, a commodity produced very largely by Englishspeaking estate owners, not Afrikaner farmers, absorbed so disporportionate a share of the state revenue which underwrote agricultural expansion in these years. The political processes and mechanisms underlying this transfer require further historical analysis. Part of the explanation has to do with the concern by the state to maintain national self-sufficiency and expand agricultural exports; if sugar cost relatively more to support because of the highly competitive international market, it was nevertheless seen as essential to do so. Part 
had to do with the significance accorded sugar as an item of consumption. The complex financial arrangements underlying subsidies, based on tariff protection rather than direct grants or price supports, perhaps disguised their extent. Sugar producers also benefited from the more general political support for agricultural subsidies. In 1926, the Amalgamated Growers Union affiliated with the South African Agricultural Union. Although Malan's Pimfied National Party criticized the 1936 Act as favouring sugar above the more essential staples such as maize, it did not oppose it.

Moreover, it is important to remember that the South African Party and the United Party, which most sugar producers supported, were in power for more than half the inter-war period. Natal was a significant source of support as Afrikaners drifted away but also had separatist tendencies. There were some powerful lobbyists for sugar interests in parliament throughout this period, particularly G Heaton Nicholls, the tireless, articulate and ruthless planter MP from Zululand. He was an important force within the SAP/United Party and highly influential in the numerous negotiations and debates. [25] He fought for the benefit of the industry as a whole but aimed always to protect its weakest link - the Zululand growers. His support for segregation policy, of which he became a major protagonist and ideologue, provided the basis for cross-cutting political alliances.

Growers and millers also benefited from their anomalous position in relation to state legislation and the bureaucracy. While both the field workers and African mill workers were deemed to be agricultural workers and thus unprotected even by the Native Labour Regulation Act (the position in the mills changed in 1937), sugar producers as a whole fell under what became the Department of Commerce and Industry. This was the state department most skilled and knowledgeable about markets, finance and the intricacies of protection, which was simultaneously being developed for South Africa's infant manufacturing plants. The anomaly caused producers no embarrassment and gave them considerable advantage.

Complaints about conditions on the sugar fields were frequent in these years of rapid expansion; they came not least from within the government itself, and more particularly from the Transkeian magistrates. [26] Bills were drafted and came close to being debated. But sugar interests either refused outright to co-operate or adopted delaying tactics. Heaton Nicholls, for example, offered a new version of the Masters and Servants Act in the late 1920 s, which would have given some discretionary power to officials to intervene, in order to head off the 1911 Act. This was rejected by officials. Official attempts to establish a hospital scheme on the estates also foundered. Sugar interests argued that any change in the sugar industry would imply change in the conditions governing agricultural employment as a whole. Ministers were not prepared to give the Native Affairs Department officials the authority to push legislation. The NAD was having to become more attuned to the demands of agrarian interests in the country and in Parliament. As an official in Pretoria in 1934 despairingly commented, they "frequently urged legislation" but "the opposition of the sugar planters has always defeated us". [27]

While the bureaucracy as a whole was relatively powerless, the intransigence of the sugar producers and ministers brought out divisions within the Native Affairs Department - and between the NAD and other departments - over the need for regulation. It was the NAD in the Transkei that had to pick up the administrative pieces of the sugar estates' excesses: to cope with unlicensed recruiters, under-age recruiting, the policing of deserters, and those repatriated penniless and sick. The Transkeian General Councils also consistently represented the plight of sugar workers to higher authority. [28] In the extensive and revealing correspondence on these issues, there is a definite sense of impatience amongst Transkeian officials with their Natal brethren, who seemed too readily to understand the needs of the sugar industry; with their colleagues in the Department of Native Labour, whose inspectors were so powerless outside industrial districts; and with Head Office in Pretoria, which engaged in shameless delaying tactics throughout the 1930s in order to evade giving any answer to the frequent representations of the Chief Magistrate of the Transkei. 
[29] It is difficult to know just how important this question was in both reflecting and causing the changing balance of power in the Native Affairs Department, but the Transkeian magistrates sometimes seemed to be treated with the kind of bureaucratic disrespect and delay that might usually be reserved for another department, or even outsiders. [30]

Thus the issue of control over child labour, conditions and health on the estates was batted around between enquiries by the Native Affairs Commission (1932), the CNC Natal (1934) and another Departmental Committee (1935) for investigation. [31] Decisions were then set aside until the Native Farm Labour Committee of 1937-1939 could investigate and report; it did so finally in 1940 and recommended exactly what sections of the NAD had been fighting for for over two decades: the extension of the Native Labour Regulation Act 15 of 1911, both to sugar estates and mills. [32]

Under the Native Law Amendment Act of 1937, however, the NAD did succeed in extending some industrial legislation to places of employment outside proclaimed labour districts where machinery was being used. This included the sugar mills, which employed about oneseventh of the workers on the estates as a whole. The field-workers and cane-cutters from Pondoland were not directly affected, but this measure was to have some important implications for the future, providing a handle for unions which coalesced on the estates during the Second World War.

\section{4. "These People, as far as I can Imagine, think they are merely acting in the ordinary course of business": youth and child labour on the estates and in the reserves}

Faka, as mentioned above, was by no means the only fourteen-year old from Pondoland who worked in Natal in the inter-war years. Through much of the twentieth century there have been recurrent exposés about youth and child labour on South African farms in general. NAD officials and African rural communities expressed concern at least from the 1910s. Occasionally, this and related issues were taken up and publicized more broadly: for example, by the Transkeian General Council, the SA Institute of Race Relations and churches in the 1930s, by the Communist Party and a couple of Unions in the 1940s, and in the ANC paper New Age and Drum magazine in the 1950s. Analysis of the issue is important not only in understanding the nature of accumulation on the farms in South Africa but also the patterns of social change in the Transkei itself.

Under the 1911 Native Labour Regulation Act, the mines were forbidden to contract youths under the age of eighteen. This measure was not uniformly and consistently imposed, but the number of employees under this age diminished. Loosely applied as it was, the restriction was acceptable to the mining industry, which needed, for the most part, men who were sufficiently physically mature to cope with the demands of underground labour. Officials approached the mining industry with the model of Victorian reforms in mind; experience of high death and desertion rates in the early years of mining provided further impetus for control.

The 18-year minimum age for recruits was, in fact, high by the standards of industrial legislation. Indeed, both farmers and officials recognized the implications of the Act in protecting the access of landlords and agricultural employers to youth and child labour. In 1911 , the Chairman of the Natal Sugar Association calculated that "taking the ordinary vital statistics of the world there would be at least 63,000 men between 14 and 18 years of age" available in Natal. The sugar estates would thus "have a very large number of useful native labourers untouched by the recruiters from Johannesburg". [33] The restrictions on youth recruiting, in which agricultural employers did not have to compete with the mines, was one reason for the sugar estates' antipathy towards the extension of Act 15 of 1911.

Officials were not, however, simply attempting to resolve the competition for labour in the country by sharing out the supply on the basis of age. The government did promulgate 
regulations in the 1910s and 1920 s to establish that only youths of 16 and above could be recruited for agriculture and that parental permission had to be obtained for the contracts involving 16- and 18-year olds. Officials were not empowered to prevent the employment of youths under sixteen on farms where parents agreed to it, nor were they particularly concerned about such arrangements where they formed part of a tenancy agreement with parents living on the farm. Undesirable child labour, from the viewpoint of officials trying to control recruiters, was construed to mean longer-term contracted labour performed away from home by those under sixteen, or those under eighteen without parental authority. Child labour was seen to lead to high rates of desertion, to the erosion of parental and "tribal" control, to juvenile delinquency and uncontrolled urbanization.

Under-age recruiting proved very difficult to control in these inter-war years, even where officials attempted to do so. Unscrupulous recruiters contributed to the problem, but its persistence rested on employers' perceptions that youth and child labour was useful and economic: either because it was cheaper, or because it was the only labour obtainable, or because children were thought to do some tasks better. Indian families had sometimes worked as a whole on the sugar fields and estate owners had initially sought to replace some of their Indian workers with settled family labour.

Under-age workers did not usually perform the heaviest work of cane cutting and loading, nor did they work in the mills. But women or children were seen as adequate for many of the other tasks, such as hoeing, weeding, herding and leading oxen - used in large numbers for ploughing - or work around the (still small-scale) compounds. The very rapid extension of the area under cultivation in the 1920 s put a premium on a cheap supply of workers for these sorts of tasks.

\begin{abstract}
Although the issue of under-age recruiting arose particularly in relation to the sugar estates and other major agricultural employers of migrant workers, planters were by no means unique in recognizing the value of youth and child labour in South Africa at this time. The fact that all African male workers were insultingly called "boys" by white employers should not disguise the reality that a good many outside the mining and industrial sector were boys or youths in the earlier decades of this century. In a segregationist era, African children were perceived in a different light from European children, for whom education was already compulsory. In Natal, particularly, the majority of urban domestic servants were African male youths from about twelve to twenty years of age. [34] Child labourers from the Transkei were used for coal loading in the Durban docks in the early 1920s, running up steep gang planks with baskets of coal. These "Grimy Imps of the Wharfside", some "mere picannins of 12 ", were presented as "grubby but happy" and their employment justified on the grounds of their "extraordinary agility". [35]
\end{abstract}

If urban employers found a range of roles for youths and children, this was even more the case in the rural areas. The practice of absorbing children into domestic and agricultural labour on farms was deeply rooted in both slave and non-slave systems. [36] Labour tenancy. was becoming the predominant social relationship on white-owned farms in the early decades of the twentieth century and the transfer of the labour of children to the landlord was part of many such agreements. As on the sugar fields, herding, domestic service, hoeing and weeding could all be done by African boys and girls or youths. Masters and Servants legislation, and court cases testing this, allowed parents to bind their children under the age of sixteen as part of a contract for the family as a whole. The Native Service Contract Act of 1932 entrenched the responsibility of the heads of African tenant households over the labour of their families as a whole in a context where both they and white farmers were finding it increasingly difficult to control the youth. The age to which fathers could bind their sons in contracts was increased to 18 . The difference between sugar planters and farmers in general was not that they assumed the availability of African youth and child labour but that they were employing children from Pondoland away from home and often without parental permission. 
When chiefs and General Councillors in Pondoland began to make representations and to demand action about the recruiting of youths and children in the $1920 \mathrm{~s}$, they tended to blame the sugar recruiters for contributing to the general breakdown of parental authority.

However, the reminiscences of old men from Pondoland who worked on the fields do not always recall coercive means of recruiting being used. This is not to say that the youths were happy in their sacks - the usual working apparel on the sugar fields; rates of desertion were high. But they were not generally forced to go and work in Natal. Mcetywa Mjomi recalled:

\begin{abstract}
It was very easy to join in those days. Boys ran away from herding cattle. They were doing it without the permission of their parents - who were complaining about it. Sugar recruiters would approach them and would send someone to collect the boys. They would follow them by night to a certain spot and they would be taken away early in the morning. [37]
\end{abstract}

An analysis of child labour on the estates must also address the issue of why youths in Pondoland might have wanted to "run away". Rural poverty, especially in the years after the First World War, was one side of the equation. But the importance of child labour in African society and the social stresses within the homesteads in the Transkei were another. [38]

Control of the labour of male children and youths was as significant in the African reserves and amongst African sharecroppers as it was on the farms. The critical task of herding was very largely entrusted to boys and youths under eighteen, and usually under sixteen. In this sense, emergent capitalist agriculture incorporated elements of the established local division of labour. Pre-capitalist and peasant labour relationships were embedded in broader kin relationships and in an ethic which made them part of socializing processes. Herding for boys involved education about the natural world and about custom, the formation of friendship networks, and the learning of fighting skills. The pace of work was also very much shaped and determined by the social practices of the youth: there was time for enjoyment. Work was part of a domestic environment, supervised by family members, and not an impersonal wage relationship.

Clearly, the notion of "work" used in describing wage labour relationships is inadequate to capture that in pre-capitalist or even peasant communities. Nevertheless, herding was work which demanded considerable skills, entailed responsibility, and could involve hardship. It is not necessary to accept views of African society which see the division of labour within the pre-colonial homestead as constituting class exploitation in order to make this point. [39] Cattle and sheep sometimes had to be taken long distances to suitable pasture or water; they had to be defended; animals had to be kept from fields during the growing season, from October to May. Punishment, including violent punishment, could be meted out to herds who let their animals into fields.

It is also important not to see the division and nature of labour in African communities as static, particularly not in the early decades of the twentieth century. Patterns of crop production and stock-keeping, as well as the entrenchment of migrant labour, altered the nature and division of labour in the homesteads. Conflict between fathers and children in many peasant societies develops not least because the whole family has to work and the family, rather than other social institutions, has to socialize youths into their duties.

Thre is some evidence to suggest that labour demands on boys and youths in Pondoland were increasing at the time when child labour became prevalent on the sugar estates. The primary reason for this was the rise in the number of animals in the area. In 1912/13, East Coast fever, a tick-borne disease, had decimated the herds. When dipping became effective, the number of cattle in Pondoland increased at an enormous rate from well under 100,000 in 1915 to about their pre-ECF level of 250,000 in $1923 / 24$, and to over 500,000 by 1930 . The number of sheep also increased nearly threefold to over 550,000 in the two decades before the drought of the early 1930s. Because of the growing numbers of animals and the 
declining quality of the pasture, stock had to be taken further each day (and returned to kraals at night) for grazing. They had to be kept from the cultivated fields, the number and density of which were also increasing. And this was the very time at which youths and even children were beginning to migrate to work, thus throwing more responsibility on the younger herders who stayed behind. While patterns of herding were flexible in relation to the numbers of animals that could be handled, the scale and pace of the increase involved presented not only a major - and often noted - ecological problem but also a labour problem.

Nor were African communities unstratified. Some homesteads had few, or even no, cattle. This was seldom a permanent state in Pondoland in these years, in that cattle could be loaned from wealthier families or bought with wage income. Nevertheless, there were always some families whose boys would herd for others rather than working for their own homesteads. In earlier years this would usually involve an exchange of labour, often between kin, for the loan of animals. By the inter-war years there could be a payment, or at least the expectation of it. Larger stock owners, who sometimes had hundreds of animals and were reluctant to loan all of these out under the ngoma system, would need to employ people on a more regular basis. Some European traders in the reserves had become large stock owners who also employed youths to herd for them. Thus herds within the Transkei itself were no longer always working for their own homesteads and the payment they received for themselves (a goat or a sheep worth less than ten shillings for three months), or a loan animal for their families, seldom amounted to what they could earn away from home.

It is not easy to get at the changing nature of herding through the oral material because the experience is part of a social memory of childhood. This tends to be expressed in romantic terms - justifiably so in the sense that the 1920 s and 1930 s were a period when cattle stocks were high and rural society in the Transkei far more independent. But the tension of the relationship is expressed in contemporary documents.

I know of two boys from my location who ran away and were recruited by a trader in the Lusikisiki district ... They went off to a certain kraal and got the kraal-head to come and impersonate their parents and they paid him something for doing this. In this way those two boys went off to the Sugar estates. We require our boys to herd our stock and yet they can run away from us by doing this. [40]

A number of men interviewed used the expression that they "ran away from herding" or from school around this time.
I had to hide away because I was running away from school ... I thought I'd be rich in no time if I left school and went to work. When I arrived there [Tongaat], I had to clean the stables where the mules were kept. I liked that work because it was not hard. When I returned my father was angry. [41]

This was not the only set of circumstances that drove youths on to the sugar estates: boys could go to work to earn money for education which their parents denied; fathers could send their children to earn money or a cattle advance; in one case, a father sent his fourteen- and twelve-year old sons to complete a contract when he fell ill. (They deserted.) [42] But it does seem that the demands on youths were being intensified at the same time as options broadened. Many white farmers, African tenants and homestead heads tended to assume that child labour, in different forms, was available for use. The question was who was going to have access to it and under what conditions.

Notions of pre-industrial or peasant child labour should not be equated with industrial child labour. Ideas about what constituted childhood were themselves being reformulated by both whites and blacks. Segregationist ideas allowed distinctions to be made in the dominant 
society between African children and white children; these gave rise to considerable unease amongst some officials, and reformist whites and blacks. But African child and youth labour was being moulded into a more capitalist context from a base where it was widely assumed by many of the parties involved that African children should work.

In this, as in many other respects, it is possible to argue that the labour practices of emerging capitalist economy in South Africa were significantly shaped by the practices, expectations, conflicts in African communities. Reformers seeking to pursue what they saw as a more rational view of capitalism were having to confront rural African perceptions as well as the excesses of employers in these inter-war years. Rural attitudes were certainly changing as educational possibilities became more widespread, but the issue was still alive in the conflicts after the Second World War over rehabilitation and fencing. It should not be assumed that Transkeian homestead heads opposed child labour on the sugar fields for the same reasons as did paternalistic officials or educated African leaders.

\section{Postscript: "In ... regard ... to the lack of state supervision over the lawless detribalised natives ... the Sugar Industry is innocent" [43]}

By the time the South African Sugar Association submitted its evidence to the Fagan Commission of Enquiry in 1947, when peak-season field-worker numbers had increased to about 50,000 , the leaders of the industry claimed innocence in relation to disrupting "tribal" society. They had become, instead, keen advocates of it - arguing for the full range of policies that underpinned apartheid: migrant labour, development of the reserves, renewal of chieftaincy, restoration of "tribal" controls, control of urbanization. They saw themselves as making a major contribution to this end.

The seasonal nature of the active operations of the Sugar Industry make it uneconomic for the full native labour force to be permanently engaged, and the rotation of life between work and their home in the Reserves is complementary ... [44]

These claims seem disturbing in the light of their enormously disruptive employment practices in the inter-war years. But although youth and child workers continued to be employed on the fields, it seems that they declined in importance from the late 1930s. The shift in employment practices was again the result of a complex interaction between changing patterns of production, on the one hand, and the way in which rural communities offered their workers, on the other.

Production of cane, it has been mentioned, quadrupled in the inter-war years. Whereas the doubling of production from about 1918 to 1932 was achieved largely by expanding the area of sugar cane reaped each year, the spectacular increase from about 1932 to 1940 , immediately after depression, drought and locusts, was achieved with relatively little expansion in the acreage reaped, but rather through gains in yield and productivity. Perhaps the major factor in this development was the change in the type of cane grown.

In the 1880 s, Natal planters adopted the Uba variety which was tough and had low sucrose content but was hardy and could withstand disease and drought. By the 1920s, Uba itself was becoming susceptible to disease and yields were less certain. Planters turned to new Coimbatore varieties developed in southern India, which were quicker growing, higher yielding and easier to cut. In 1935 , about 85 per cent of the cane reaped was still Uba; in the next three seasons this figure declined to about 30 per cent. [45] Pricing and marketing agreements rewarding high sucrose content in cane encouraged a rapid switch. Increased yields, coupled with generous state price supports in this period, stimulated simultaneous investment in plant, in fertiliser, and in physical works and contouring on the land. 
There was no guarantee that this favourable conjuncture would result in rewards for workers. In 1939, the estates refused to follow many other industries in meeting some of the travel costs of their migrant workers. As the Social and Economic Planning Council mentioned, crops such as sugar were being subsidized not only by the mining industry and producers of other less protected agricultural commodities but also by the "lowly-paid unskilled workers". [46] However, the change in the type of cane put a premium on cutting skills. Moreover, some estate owners began to perceive that they could save costs by getting more work out of fit and mature men rather than relying on a large turnover of less productive workers. By the second half of the 1930 s, bonus systems were being introduced on the leading estates for every $100 \mathrm{lbs}$ cut over the basic minimum task per day: usually 3-3,500 lbs of Coimbatore. The standard wage in the inter-war years was about $£ 2$ for a ticket of thirty days, in contrast to $£ 3$ on the mines. This declined in 1932 to between 30 and 35 shillings. But wage rises to $£ 2$ in the late $1930 \mathrm{~s}$, coupled with the bonus payments, attracted more mature men back on to the fields.

Leading estates like Tongaat began to make major reforms in their employment practices in the 1930s. Credit for these are claimed for Douglas Saunders, who returned from Cambridge University to take over the Tongaat estate in the late 1920s. [47] Park Ross of the Department of Health was perhaps more significant in putting persistent though politic pressure on the planters over a long period of time. He used what purchase was given by the Public Health Act to attempt to enforce some minimum housing standards; he also drew up and advertised minimum diet schedules for workers - though these were largely ignored.

Devastating malaria epidemics in the late 1920s and early 1930s also helped to shock the state and planters into further action. [48] Spreading southwards from parts of Zululand where it was endemic, malaria penetrated deep into the North coast sugar belt, especially in $1929 / 30$, and took the lives of thousands. Workers from the Transkei and southern Natal, who were hardly exposed to the diseases at home, were particularly vulnerable. Medical officers made a clear link between the rates of death and the general housing and health conditions in particular compounds. [49] Major estates were brought to a halt for weeks during the harvest and crushing season. A renewed campaign by the Department of Health to improve conditions was launched. But it was only around 1940 that even the leading miller/planter concerns were meeting the full dietary recommendations of the Department of Health - to include meat twice a week, citrus and vegetables, as well as a full supply of maize and beer. [50]

The malaria epidemic also benefited migrant workers from the Transkei in that the Health Department prevailed on the government to prevent recruitment from non-malarial zones into malarial areas such as the Zululand estates. Those estates with the worst conditions, those most dependent on cheaper labour, were thus closed to migrants from Pondoland. The government also reluctantly agreed to maintain some restrictions on mine recruiting in the sugar districts of Zululand, a measure which had important implications for Zulu workers.

Shifting employment practices, which were in turn related to the changing patterns of sugar production on the major estates, were partly responsibnle for an apparent decline in some of the worst features of Transkeian child migration. Estates had often found youths and children to be particularly troublesome employees. The prevalence of violence as a means of control on the sugar fields was in part related to the proportion of sick workers and young workers unaccustomed to industrial discipline. Although cheaper than adults, youths seem to have deserted more frequently; as they were not registered for tax purposes and their contracts were not always attested by magistrates, they could be difficult to trace. It was not always disadvantageous to dispense with child labour.

There was no legislative guarantee that the improvement in conditions in the sugar fields would be sustained. There had, in any case, been little change on many estates, especially on the lands of more marginal planters. Moreover, during the 1940s the sugar estates, following their extraordinary expansion, experienced slump and uncertainty. Production did not again 
exceed the heights of 1940 (nearly 600,000 tons) until 1954. Serious droughts, coupled with inflating costs, discouraged further investment and expansion; fertiliser was difficult to obtain because of the Second World War. The government also held down the domestic price of sugar, a basic item for working-class consumers, during the inflationary years of the War and immediately afterwards, when industrial militancy was widespread. The internal market expanded, not least because a cheaper grade 2 unrefined sugar was produced in large quantities, following the 1936 Sugar Act and the subsequent Sugar Industry Agreement. [51] But producers could not meet their export quota. Only in 1947 did the government allow a significant internal price hike, as internal prices for agricultural commodities such as sugar rose. The National Party government then reaffirmed state commitment to an expanded industry, including exports, at a time when opportunities for sugar production improved as a whole.

The conditions of the Second World War not only saw the state acting to protect low-income consumers at a time of industrial conflict, but planters were increasingly having to operate in a highly competitive labour market for migrant workers. Some workers from Pondoland began to shift away from the mines and sugar fields towards expanding manufacturing industries. In this context sugar workers could assert themselves more forcefully. Indian workers still predominated in the mills by the late 1930 s, when a new phase of trade union organization began. [52] The Communist Party had recovered from the worst of its inter-war purges and some key figures in the Indian community were recruited. Natal Indian industrial workers became perhaps the most highly unionized segment of the black South African work-force in the late 1930 s and the 1940 s.

Unionists made extensive use of the industrial legislation available and their efforts were not confined to Indian workers alone. The Sugar Industry Employees Union was registered in 1938 under the Industrial Conciliation Act. [53] Following the Native Laws Amendment Act of 1937, African workers in the mills also qualified as workers under the industrial and wage legislation. In 1940, the Union approached the Wage Board for an official investigation of wages and tried to include even field workers in the process. A protracted dispute followed and the Labour Ministry under Madeley, reluctant to risk a full-scale strike in a strategic industry during the war - especially with the additional threat that cane fields might be fired made an award to the mill workers.

Field workers were not included in the agreement, but employers were correct to fear that any wage rise in the mills was bound to have repercussions in the fields. The war years were punctuated by small, dispersed strikes by non-unionized field workers, including those from the Transkei. In 1942 wages crept up to $£ 2.10$ s. for thirty tickets on leading estates. Following the success of the African Mine Workers' Union, the Communist Party extended its organizational commitment to unskilled migrant workers. In Natal, MP Naicker, W Cele and others launched a Natal Sugar Field Workers' Union, which again attempted to bridge Indian and African workers. In this case, however, the union had no industrial legislation under which to operate and received no recognition. The Field Workers' Union, like the Mine Workers' Union, crumbled in the late 1940s. But it did succeed in publicizing conditions on the estates at a sensitive period and certainly caused a good deal of official concern. Such pressures, together with the other longer-term shifts in production methods and conditions of employment, seem to have limited the reversion to widespread under-age recruiting. In the $1950 \mathrm{~s}$, when the industry again expanded very rapidly to reach new heights of production, the system of migrant labour came to replicate that on the mines more closely.

Important social changes in the rural areas also contributed to the entrenchment of a less disruptive system of labour migration from Pondoland. Firstly, if the argument about the relationship between increasing animal numbers and child labour is correct, then it must be qualified for the period after the mid-1930s. Stock numbers fell in the droughts of the early 1930 s and subsequently stabilized. Secondly, school facilities and also demand for schooling expanded in the $1940 \mathrm{~s}$, a process which accelerated in the $1950 \mathrm{~s}$ when the introduction of Bantu Education was accompanied by rapid increases in funding for rural schools. Thirdly, 
migration to the cities, especially Durban, by women and children as well as men became more general in the Second World War. Population was actually stable from 1936 to 1946 in some Pondoland districts.

Youth migration was still strongly encouraged. With official sanction, a pattern developed whereby many workers would take a few contracts on the sugar fields between the ages of about 16 and 20. They would then move on to the Rand, or to industries in Durban, unless the opportunity of upward mobility on the estates presented itself. But if the worst excesses of child labour had perhaps been resolved on the sugar fields, the same could not be said of a number of other agrarian contexts in the 1950 s.

Analysis of the pattern of employment on the sugar fields in the period from the 1930 s, and of the experience of Transkeian workers there, suggests some generalizations about the material basis of apartheid which need to be tested. Wolpe and Legassick argued in different ways that one feature of the transition from segregation to apartheid was the extension of the migrant labour system from mining to manufacturing industry in order to broaden the supply of cheap labour. This argument has been contested and modified in various ways: the pass laws were unevenly applied; considerable African urbanbization continued; and a highly differentiated African labour force emerged. Morris has pointed to the importance of the agrarian labour crisis of the 1940 s, as much as the industrial labour supply, in shaping early policies of the nationalist government. [54]

Perhaps more attention should be focussed on the partial shift towards migrant labour in agriculture. It is clear that major elements of the apartheid programme were linked to changing patterns of agricultural employment. [55] The significance of this sector should not be neglected for the early apartheid years. In the period 1945 to 1955 agricultural production grew as a proportion of the GDP (9.4\% in $1945 ; 17.8 \%$ in $1950 ; 15.1 \%$ in 1955$)$, temporarily reversing a trend in the opposite direction over the previous and subsequent decades. Systems of tenancy did persist in many contexts and were sometimes replaced by wage labour settled on farms. But it was not only on the sugar estates that a shift to migrant labour, as part of an overall trend towards wage labour rather than tenancy, took place. How far the ideology of capitalist farmers reflected the positions reached by the sugar planters after the Second World War requires further investigation: it was surely significant in the elaboration of apartheid.

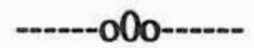

Notes

1 NTS 2048 71/280, Annexure B to file 65/280, part III. "Report by Committee to Enquire into: (1) The mortality amongst natives at Izingolweni who were returning home from the sugar estates, and (2) The general medical attention on the sugar estates in Natal": E J Larsen, Station Master, Izingolweni, to Magistrate Harding, 6 January 1922. All material in this section is taken from this file.

2 Ibid.

3. Izingolweni served another important function as soon as it was built. In 1912/1913, the devastating tick-borne cattle disease of East Coast Fever reached Pondoland, having 
made its way slowly through Natal in the previous few years. Ox-wagon transport was greatly disrupted and Izingolweni quickly became a railhead for goods moving in and out of Eastern Pondoland. See W Beinart, The Political Economy of Pondoland (Cambridge, 1982), chapter 3. Railways have not yet penetrated into Pondoland. However, most rail traffic now goes via Umtata or Kokstad and most passenger traffic into Natal is by bus. Izingolweni, picturesque under a canopy of tall gum trees, remains a small station.

4. NTS $204871 / 280$, Larsen to Magistrate Harding, 6 January 1922. Larsen exaggerated the distance. While the wagon road from Izingolweni to Lusikisiki via Bizana, Emagusheni and Flagstaff was a good 100 miles, most migrant workers walked straight overland and slept in homesteads on the route which cut the distance by about half.

Ibid.

Ibid.

7 NTS 71/280, Report of Committee. The subsequent parts of this section are based on the report itself, except where otherwise mentioned.

8 NTS $204865 / 280$, vol III, Annexure C, CMT to SNA, 4 June 1924, enclosing minutes of discussion at Transkeian Magistrates' officials conference.

9 NTS 7048 65/280, part I, Chairman, Natal Sugar Association, speech on 19 September 1911, as reported in Natal Mercury, 20 September 1911.

10 The words come from a white Natal Provincial Councillor. HEN 1092 135/4, vol II, Article by R Feldman, MPC, in Illustrated News, 13 February 1946: "We don't want sweated sugar."

11 Bill Albert and Adrian Graves (eds), Crisis and Change in the International Sugar Economy (Norwich, 1984); Peter Richardson, "The Natal Sugar Industry in the Nineteenth Century" in W Beinart, P Delius and S Trapido (eds), Putting a Plough to the Ground (Johannesburg, 1982); Maureen Swan, Gandhi. The South African Experience (Johannesburg, 1983).

12 NTS 7048 65/280, part I, Chairman, Natal Sugar Association, speech on 19 September 1911, as reported in Natal Mercury, 20 September 1911.

13 P Harries, "Plantations, Passes and Proletarians: labour and the colonial state in nineteenth century Natal", Journal of Southern African Studies (JSAS), 13, 3 (1987); A Jeeves, Migrant Labour in South Africa's Mining Economy (Kingston, 1985).

14 Swan, Gandhi; M Swan, "The Natal Indian Strike of 1913", JSAS, 10, 2 (1984).

15 NTS $704865 / 280$, vol 1 , for records on the problems of labour supply.

16 Harries, "Plantations, Passes and Proletarians".

17 See R Morrell, "Competition and Cooperation in Middelburg, 1900-1930” in Beinart, Delius and Trapido, op cit., p 394, for attempts by Bethel and Middelburg maize potato farmers, such as Lazarus, to find a similar supply.

18 NTS 7048 65/280, Edward Dower, Secretary of Native Affairs, to Henry Burton, Minister of Native Affairs, 26 September 1911. A departmental committee into the "Alleged shortage of Native labour in the Natal province was appointed" to report in 1918. For inspections of conditions on the fields, see Natal Archives, CNC 
$358 / 1465 / 1919$.

19 No central record was kept of the number of migrant workers from Pondoland on the estates; passes were not always obtained nor are pass figures available for this period. These figures are based on estimates made by government sources int he course of one or other of the detailed enquiries into the sugar industry.

20 Beinart, Pondoland.

21 See section 4 below.

22 NTS 2048 65/280, vol II, note on J Mould Young, CMT to SNA, 2 July 1934.

23 A G Hammond, South African Cane Growers' Association. The First 50 Years, 1927-1977 (Durban, 1977), is a detailed treatment of tariff issues and legislation. The book, like the South African Sugar Journal which Hammond edited, makes little mention of sugar workers. For Mozambique, see L Vail and L White, Capitalism and Colonialism in Mozambique (Minneapolis, 1980), chapter 5. Conditions and wages on Hornung's giant Sena Sugar Estates in Quelimane were worse than in South Africa.

24 Union of South Africa, Social and Economic Planning Council, The Future of Farming in South Africa, report No 4, UG 10 - 1945.

25 Hammond, First 50 Years, passim. Shula Marks, "Natal, the Zulu Royal Family and the Origins of Segregation", JSAS, 4 (1979); S Marks, The Ambiguities of Dependence (Johannesburg, 1987).

26 There is extensive correspondence in NTS 2042048 65/280 and subsequent files.

27 See note 22.

28 The Pondoland General Council covered the three Western Pondoland districts from 1913 to 1927 when the four Eastern Pondoland districts were incorporated. In 1931 the PGC was merged with the Transkeian Territories General Council to form the United TTGC which met annually. Debates were recorded.

29 There was considerable interchange between the Natal and Transkei sections of the service although less so between these and the DNL and head office. J Mould Young, the CMT in the 1930s, had served as CNC in Natal; Pringle, the Lusikisiki Magistrate in the early 1930 s, had also been a key Natal Magistrate. However, they became increasingly concerned about the issue when serving in the Transkei, and Lugg, the Natal CNC from 1934, seemed to be more sympathetic to the planters.

30 S Dubow, "Holding 'A Just Balance between Black and White': the Native Affairs Department in South Africa c1920-1933", JSAS, 12, 2 (1986).

31 Union of South Africa, Report of the Departmental Committee appointed to Enquire into and Report upon Certain Questions Relating to Native Labour in Zululand, the Transkeian Territorties and the Ciskei (Pretoria, 1935). For report and minutes of evidence, see NTS 2202 315/280

32 Union of South Africa, Report of the Native Farm Labour Committee, 1937-39 (Pretoria, 1939), paragraph 496, p 207.

33 NTS 7048 65/280, report in Natal Mercury, 20 September 1911. 
34 P la Hausse, "Mayiholome! Towards an Understanding of Amalaita Gangs in Durban c1900-1930", unpublished paper, 1988. An earlier version was presented in 1987 to the African Studies Institute Seminar, University of the Witwatersrand. See also C van Onselen, "The Witches of Suburbia", in Studies in the Social and Economic History of the Witwatersrand (London, 1982).

35 GNLB 252 357/10/98, enclosing newspaper cutting. Reference from Paul la Hausse.

36 P Delius and S Trapido, "Inboekselings and Oorlams: the creation and transformation of a servile class", JSAS, 8, 2 (1982); T Keegan, Rural Transformations in Industrialising South Africa (London, 1987), includes the most developed analysis of African family labour on white-owned farms.

37 Interviews: Mcetywa Mjomi, Amadiba location, Bizana, 16 April 1982; Meje Ngalonkulu, Mtayiso location, Bizana, 7 April 1982; Phato Madikizela, Amangutyana location, Bizana, 12 April 1982.

38 Beinart, Pondoland; M Hunter, Reaction to Conquest (Oxford, 1936, 1964).

39 J Guy, "Analysing Pre-Capitalist Societies in Southern Africa", JSAS, 14, 1 (1987), for a recent restatement of this position.

40 Pondoland General Council, 1929, 57-58, speech by Councillor Soxujwa, Lusikisiki.

41 Interview, Phato Madikizela, Mbongweni, Bizana, 12 April 1982.

42 Cape Archives, CMT 3/604/49, for the case of Govuza who deserted in 1921. Interview, Leonard Mdingi, June 1982.

43 University of Cape Town library, MS BC 630, "Memorandum dealing with the conditions of Native Labour in the Sugar Industry for Submission to the Natives Laws Commission of Enquiry", South African Sugar Association, 8 January 1947.

44 Ibid.

45 Figures are taken from the Agricultural Censuses which recorded, in these years, both the acreage of Uba and other canes planted and reaped.

46 Social and Economic Planning Council, The Future of Farming in South Africa.

47 R G T Watson, Tongaati. An African Experiment (London, 1960); P van den Berghe, Caneville. The Social Structure of a South African Town (Middletown, Connecticut, 1944).

48 The epidemic is dealt with in greater detail in a longer version of this paper, based on material in the Department of Health archives, GES 585 36/12 and 2624-2628 6/56.

49 GES $26246 / 56$, vol 1, "Report on Investigations into Malaria Epidemic. Stanger, Mtunzini and Eshowe Magisterial areas", Government Pathologist et al to Assistant Health Officer, Durban, 11 June 1929, and J Alexander Mitchell to Prime Minister, 31 July 1929; cf Randall M Packard, "Maize, Cattle and Mosquitoes: the political economy of malaria epidemics in colonial Swaziland", Journal of African History, 25, 2 (1984), pp 189-212.

50 NTS $204865 / 280$, Report on visit by SNA D Smit to Natal Sugar estates.

51 Hammond, The First 50 Years, chapter 10. 
52 Maureen Swan, "Organised Indian Politics" in S Marks and S Trapido (eds), Race, Class and Nationalism in Twentieth Century South Africa (London, 1987). I am indebted to Maureen Swan for discussions of this period as well as access to material from her interviews with Rowley Arenstein, 15 April 1983, and R D Naidoo, 3 May 1983.

53 Union activities in the sugar industry are the subject of considerable correspondence in NTS 2049 65/280 and HEN 1092 135/4.

54 M Morris, "State Intervention and the Agricultural Labour Supply post-1948" in F Wilson, A Kooy and D Hendrie (eds), Farm Labour in South Africa (Cape Town, 1977); D Hindson, Pass Controls and the Urban African Proletariat (Johannesburg, 1987).

55 L Platzky and C Walker, The Surplus People: forced removals in South Africa (Johannesburg, 1985); M Lipton, Capitalism and Apartheid (London, 1985). 